\title{
BIOLOGY
}

\section{Biology of a trap-nesting wasp of one species the ground-nesting Liris (Hymenoptera: Crabronidae) from the Atlantic Forest of southern Brazil}

\author{
Camila Cristina Ferreira da $\operatorname{Costa}^{1^{*}} \&$ Maria Luisa Tunes Buschini ${ }^{2}$
}

\begin{abstract}
'Programa de Pós-graduação em Entomologia, Departamento de Zoologia, Universidade Federal do Paraná. Centro Politécnico, Avenida Coronel Francisco H. dos Santos 210, Jardim das Américas, 81531-980 Curitiba, PR, Brazil. 2 Programa de Pós-graduação em Biologia Evolutiva, Departamento de Biologia, Universidade Estadual do CentroOeste. Rua Salvatore Renna 875, Santa Cruz, 85015-430 Guarapuava, PR, Brazil.

"Corresponding author. E-mail: dacosta_camila@yahoo.com
\end{abstract}

\begin{abstract}
Studies on the nesting biology of Liris are restricted to a few notes and observations on ground-nesting species. There are no studies of this kind about Brazilian species. We investigated and described the nesting biology of Liris sp. obtained by trap-nests that were installed at an area of Atlantic Forest vegetation $\left(25^{\circ} 10^{\prime} \mathrm{S}, 48^{\circ} 18^{\prime} \mathrm{W}\right)$ in southern Brazil. The nests of Liris sp. are built with a variety of plant debris. They usually have one cell, but may have up to two. Nests do not show vestibular or intercalary cells. Immatures have a hard cocoon made with the silk they produce, mixed with the fine sand and sawdust left by the adult female at the bottom of the cell. No nest parasites were observed. The wasps did not go through diapause at the prepupal stage, and emerged within 36 to 46 days after nests were collected from the field. There was no emergence of male wasps. Even though Liris sp. nest in preexisting cavities, they resemble ground-nesting species of the same genus in their habits, nest architecture, and development characteristics. The absence of males in our samples might be related to nest diameter. The eggs from which males hatch can be laid in smaller burrows than those available at the present study. We believe that the hardiness of the cocoon is the species' main strategy against parasites, although it is complemented by the camouflage provided by the nest closure. We suggest that a broader comparison of the nesting biology of Liris Fabricius, 1804 should be carried out, leading to a better understanding of the evolution of nests in the genus.
\end{abstract}

KEY WORDS. Burrow, cocoon, nesting biology, parasites, solitary wasp.

Crabronidae wasps, with a few exceptions, are hunters of a great variety of insects and spiders. This family includes solitary digger wasps, mud-daubers and sand wasps that nest in soil and preexisting burrows in wood, using mud and plant material to build their nests (BOHART \& MeNKe 1976). Crabronidae is represented in the Neotropical region by 1,640 species, 545 of which have been recorded from Brazil (AMARANTE 2002).

Liris Fabricius, 1804 is a predominantly pan-tropical genus of solitary ground-nesting cricket-hunting wasps with 314 species worldwide (PULAWsk 2015). Despite their worldwide distribution, little is known about the Neotropical fauna of Liris, which is expected to reveal many new taxa in future taxonomic studies (Krombein \& Gingras 1984). Liris is the fifth richest genus of the Crabronidae (Morato et al. 2008). There are 75 species described from the Neotropical region (AMARANTE 2002), 21 of which occur in Brazil (Menke \& Fernández 1996, Amarante 2002).

Liris species usually make their nests in the ground by digging or using preexisting burrows (KROMBEIN \& GINGRAS 1984).
Nest closures and cell divisions are made with a large diversity of materials, from sand and small stones to wood chips and different plant materials (Steiner 1968, Krombein \& Gingras 1984). Brood cells are provisioned with nymphs and adults of Gryllidae (Steiner1968, Bohart \& Menke 1976, Krombein \& Gingras 1984). The main differences of nest architecture among species of Liris are due to diameter and length, angle in relation to the ground, and number of cells (STEINER 1968, BOHART \& MENKE 1976, Kurczewski 1976, Krombein \& Gingras 1984).

Studies in Brazil using trap-nests have documented a high abundance of wasps of the genus Trypoxylon Latreille, 1796 (Crabronidae) and many genera of Eumeninae (BATISTA-Matos et al. 2013, Buschini \& Woiski 2008, Nascimento \& Garófalo 2014). Bees and other wasps are usually less abundant. As far as we know, no published studies have documented Liris in Brazil using trap-nests. Worldwide, only one study has documented the presence of a species of Liris using this method (STANGLER et al. 2015). It is possible that the absence of certain genera of 
wasps in studies using trap-nests in Brazil owes to the fact that sampling efforts have been restricted to open areas and early successional forest fragments (Aguiar \& Martins 2002, Loyola \& Martins 2006, Batista-Matos et al. 2013, Nascimento \& Garófalo 2014), thus restricting the species that are collected. According to MARCO-JR \& VIANNA (2005) one of the reasons for the insufficient knowledge about the invertebrate fauna of Brazil is that studies and intense sampling have been restricted to a few areas, while the fauna of other areas remains undocumented.

The trap-nest method has been largely used to collect wasp species that nidify in preexistent cavities. It is a useful and simple technique that may provide information on wasp's behavior (e.g., nest architecture, material used for nest building, nidification place, cocoon structure), phenology (life cycle) and' interactions with natural enemies (cleptoparasites and parasitoids), even after short periods of field data collection (Bosch et al. 2001, Buschini \& Buss 2014, Krombein 1967, O’Neill 2001). This information may help to solve questions about the evolution of nesting habits within groups of Hymenoptera, since nesting biology and architecture are informative phylogenetic characters (Bosch et al. 2001, Rasmussen \& Camargo 2008).

Considering the poor worldwide knowledge about the nesting biology of Liris the present study aims to describe aspects of nest architecture and life history of an unidentified species of Liris collected using trap-nests in the Atlantic Forest in southern Brazil. This is the first study from Brazil and the second in the world in which a species of Liris is recorded at trap-nest. Also, it is the first description of the nesting biology of a species of this genus.

\section{MATERIAL AND METHODS}

This study was carried out at an area of Atlantic Forest within the Natural Reserve Salto Morato (NRSM, $25^{\circ} 10^{\prime}$ S, $48^{\circ} 18^{\prime} \mathrm{W}$ ), municipality of Guaraqueçaba, coastal area of Paraná, southern Brazil. The climate there is humid subtropical with an average annual temperature of $21^{\circ} \mathrm{C}$, warm summers and sporadic frosts in winter. The average rainfall ranges from 2,000 to $3,000 \mathrm{~mm} /$ year (FGBPN 2011).

The landscape of NRSM is characterized by a mosaic of fragments of distinct successional stages, which reflect its previous land usage. Before it became protected, part of the area was used to raise buffalo herds and for small scale monocultures. The reserve is now undergoing natural regeneration.

For the present study we set our trap-nests within three different forest successional stages: areas with 20 years of ongoing natural regeneration (early successional forest), areas with 40 years of ongoing natural regeneration (intermediate successional forest), and areas of little disturbed primary forest. At each of the three successional stages we established two different sites separated by at least $1.3 \mathrm{~km}$. Thus, we had a total of six sites, two corresponding to each successional stage. Temperature data from the Reserve were provided by the local weather station.
Nests of solitary trap-nesting wasps were collected in the six sites with trap-nests from August 2013 to April 2014. The trap-nests were made out of $12 \times 3.5 \times 2.5 \mathrm{~cm}$ wooden blocks, drilled longitudinally to a depth of $8 \mathrm{~cm}$ with $0.5,0.7,1.0$ and $1.3 \mathrm{~cm}$ opening diameters. The wooden blocks were cut longitudinally in half and then held together with adhesive tape to allow examination of the cavities.

At each site we set six sampling stations with a distance of $50 \mathrm{~m}$ between them. Each station consisted of a wooden post with 16 trap-nests, four of each diameter $(0.5,0.7,1.0$ and 1.3 $\mathrm{cm}$ ) randomly placed, wrapped together by a black plastic and covered by a roof tile. Nests were placed at approximately 1.5 $\mathrm{m}$ height to provide standardized nesting sites for cavity-nesting solitary wasps. A total of 96 trap-nests per site were placed, totaling 576 traps in the entire study.

Every two weeks the stations were inspected. Each trap containing nests, which are easily distinguishable by the characteristic nest-closing plug, were collected and immediately replaced with empty traps of the same diameter. The nests were then brought to the laboratory and opened in order to investigate their contents, and then reared in plastic bottles closed with cotton wool maintained in a growth chamber at $22-25^{\circ} \mathrm{C}$, $65-85 \%$ relative humidity and photoperiod of $12: 12$ hours to complete the life-cycle (death or emergence of adult).

For every nest, we recorded the number of brood cells and the amount of prey and parasites, and the number of vestibular and intercalary cells. The length and diameter of nests were measured with a caliper. Recently emerged adults were carefully removed and had their gender determined. Head width was measured with the help of a stereoscope. This measurement was taken as the maximum distance between the external margins of the eyes.

Wasps were identified to genus using the key made by MENKE \& FERNÁNDEZ (1996). Species determination was not possible, owing to the lack of revisions and appropriate identification tools for Neotropical Liris (PULAWsKi 2015). Voucher specimens (deposits number: 172980, 172981, 172982, 172983) were deposited at the Coleção Entomológica Pe. Jesus Santiago Moure, Departamento de Zoologia, Universidade Federal do Paraná, Curitiba (DZUP).

We performed all calculations in R software version 3.1.0 (R Development Core Team 2014). We compared the cell length, cell and cocoon volumes from the different nest diameters using a student t-test. We did not use the nest of $1.0 \mathrm{~cm}$ since just one cell was collected from it. Data on the cocoon volume was log-transformed in order to follow normality assumptions.

\section{RESULTS}

\section{Seasonality and nidification activity and habitats}

In this study, a total of 11 nests of Liris sp. were collected, five at the primary forest and six at the early successional forest. No nests were collected at the intermediate successional forest. These nests were collected in February and March 2014 (Fig. 1). 


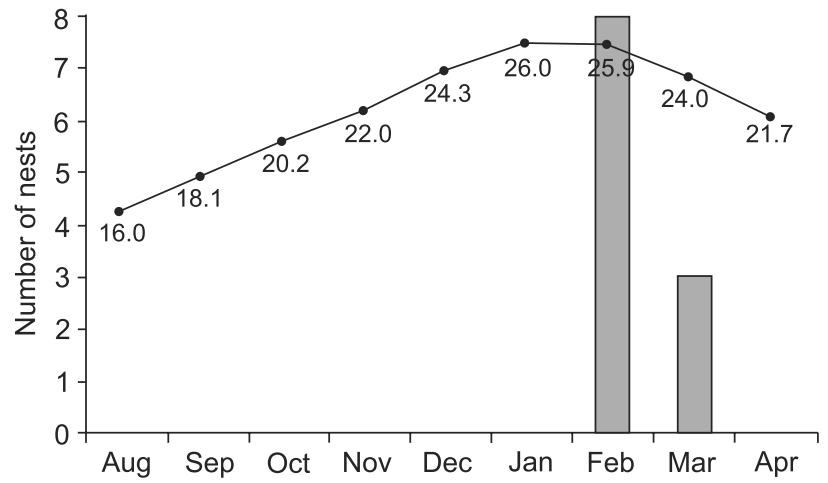

Figure 1. Mean temperature $\left({ }^{\circ} \mathrm{C}\right)$ and number of nests collected for each month from August 2013 to April 2014.

\section{Nest architecture and cell provision}

Liris sp. used all nest diameters, except for the $1.3 \mathrm{~cm}$, preferring $0.5 \mathrm{~cm}(54.6 \%), 0.7 \mathrm{~cm}(36.4 \%)$ and $1.0 \mathrm{~cm}(9 \%)$ trapnest diameters. Nests showed similar architecture regardless of trap-nest diameter. Most nests were unicelled, but two showed two provisioned cells. Both uni- and two-celled nests showed neither vestibular nor intercalary cells. Neither brood cell volume $(\mathrm{t}=-1.57, \mathrm{p}=0.15)$ nor cell length $(\mathrm{t}=1.87, \mathrm{p}=0.11)$ varied significantly in the different diameters of the nests (Table 1 ). Nest closure and cell partitions are made of a variety of plant debris, for instance: chewed wood chips, small sticks, leaves, seeds, dry fruits and sand (Fig. 2). At the bottom of the brood cells the adult female wasp leaves a mixture of fine sand and sawdust. Cells were provisioned with crickets (Ensifera) nymphs, with two to four preys per cell. Eggs were laid at the ventral part of the thorax of one of the nymphs, between the fore- and mid-coxae.

Table 1. Structure of nests of Liris sp. of different diameters and adult and cocoon measurements. Values are means \pm standard deviation. Values between blankets are the number of nests or cells measured.

\begin{tabular}{lccc}
\hline \multirow{2}{*}{ Measured structure } & \multicolumn{3}{c}{ Nest diameter } \\
\cline { 2 - 4 } & $0.5 \mathrm{~cm}$ & $0.7 \mathrm{~cm}$ & $1.0 \mathrm{~cm}$ \\
\hline Total nest length $(\mathrm{cm})$ & $7.95 \pm 0.36(6)$ & $8.61 \pm 0.64(4)$ & $8.20(1)$ \\
Number of brood cells $(\mathrm{n})$ & $1.17 \pm 0.41(6)$ & $1.25 \pm 0.50(4)$ & $1.00(1)$ \\
Volume of brood cells $\left(\mathrm{cm}^{3}\right)$ & $0.59 \pm 0.26(7)$ & $0.77 \pm 0.15(5)$ & $2.11(1)$ \\
Closure length (cm) & $4.06 \pm 0.86(6)$ & $5.91 \pm 1.21(5)$ & $6.21(1)$ \\
Number of preys per brood cell $(\mathrm{n})$ & $3.00 \pm 0.00(6)$ & $2.34 \pm 0.58(3)$ & $4.00(1)$ \\
Volume of cocoon $\left(\mathrm{cm}^{3}\right)$ & $3.33 \pm 0.83(5)$ & $0.21 \pm 0.18(5)$ & * \\
Maximum adult head width (cm) & & $0.16(1)$ & $*$ \\
\hline * Data not available. & & &
\end{tabular}

\section{Cocoon structure}

The cocoons are elongated, opaque light brown, hard and with small sand grains embedded in the internal and external walls (Fig. 4). During cocoon spinning, larvae use the material left by the adult female at the bottom of the brood cell (sand and sawdust), mixing it with silk. This mixture confers the cocoon its rigid structure, which cannot be smashed when pressed with some strength between the fingers. The volume of the cocoons does not show significant variation among the different nest diameters $(\mathrm{t}=0.14, \mathrm{p}=0.90)$ (Table 1$)$.

\section{Development period and emergence}

Four females emerged and no males were observed. Three wasps emerged from the $0.5 \mathrm{~cm}$ and one from the $0.7 \mathrm{~cm}$ diameter nests (Fig. 3). The head width of females from 0.5 and 0.7 diameter nests was similar(statistical test not applied due to small sample sizes from different nests).

The average time between nest collection and adult wasp emergence was 40 days, with minimum and maximum intervals of 36 to 43 days. Juveniles did not exhibit diapause at the prepupal stage.

\section{Mortality rate}

Nine juveniles from the 13 built cells died (69.2\%). From them, six (46.1\%) died before hatching from the eggs and three (23\%) died as pupae. The high mortality rate was not caused by natural enemies, since no cells were attacked.

\section{DISCUSSION}

The present study is the first in Brazil and the second in the world in which Liris wasps were collected using trap-nests. However, this is the first study describing Liris nest biology. The nesting activity of Liris sp. is restricted to two months in the late summer and beginning of autumn. STEINER (1968) noted a longer and earlier nidification period for Liris niger (Fabricius, 1775) from southern France, which extends from May to August (spring and summer), the months with more nest foundation at the beginning of summer, in June and July. Wasps from regions with well-defined seasons usually nest during the warmest months (spring, summer and beginning of autumn), with juveniles or adults entering diapause in the colder seasons (BusCHINI \& Buss 2014, STEINER 1968). There is therefore a variation in the months and time spam of nesting activity even among wasps of the same species, depending on the weather conditions of the region and the year the wasps are established (Ribeiro \& Garófalo 2010, Buschini \& Buss 2010, 2014).

It is common that wasps enter diapause in the pre-pupal stage, but there are some exceptions. Sometimes it occurs in adult individuals (BuschinI et al. 2007), as observed for some species of Liris. According to Krombein \& Gingras (1984), adult females of Liris argentatus (Palisot de Beauvois, 1811) from the United States remain in diapause inside ground burrows in the winter. The same was observed by STEINER (1968) for adults of L. niger from southern France. However, the lack of diapause, observed in the present study, may be influenced by the controlled light periods and temperature conditions in which the nests were kept, which may inhibit this behavior (MOURão \& PANizZi 2000). 


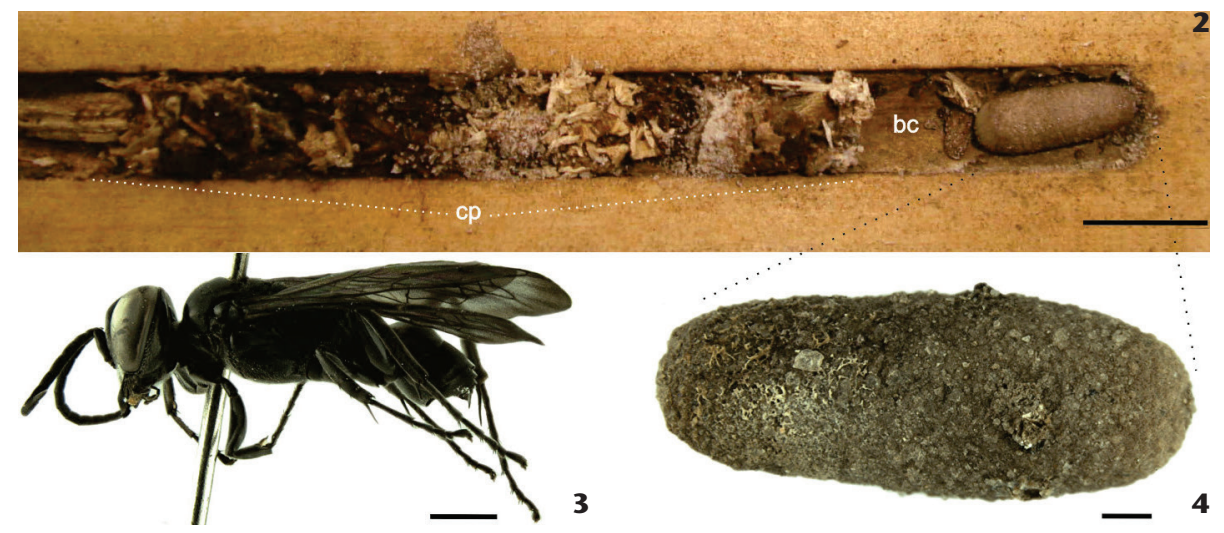

Figures 2-4. (2) $0.7 \mathrm{~cm}$ diameter trap-nest showing nest structures: closure plug (cp) and brood cell with cocoon (bc); (3) adult female; (4) cocoon. Scale bars: $2=10 \mathrm{~mm}, 3-4=1 \mathrm{~mm}$.

Among the material used by Liris sp. for nest construction, only the wood chips are different from the material commonly used by ground-nesting wasps (KROMBEIN \& GINGRAS 1984, STEINER 1968). Usually, Liris wasps make their nests from a variety of debris collected from the ground, such as sand, variable plant material (dry leaves, seeds, small sticks, petals) and small gravel (Krombein \& Gingras 1984). As stated by O'Neil (2001), it is characteristic of ground-nesting wasps to use soil and its debris, since most wasps that nidify in preexisting cavities in wood make the nest closure only with mud or mixing it with other substances. If this species of Liris uses only preexisting burrows to build its nest, instead of digging the ground as other wasps of the same genus do, it seems reasonable to conclude that the behavior of using soil debris to build the nest closure is a feature that persists in Liris sp.

Liris sp. showed preference for trap-nests with smaller diameters. It seems that the choice of diameters by the adult female wasp is influenced by its body size (Krombern 1967), the size of the prey (CAmillo et al. 1996) and availability of empty burrows in the habitat (CovilLe 1982). Even small variations in the nest diameter can determine which species had nested (O'NeILl 2001), and it was observed that some ground-nesting Liris with body size similar to that of the studied species showed preferences for larger nest diameters. For example, Liris muesebec$k i$ (Krombein, 1954) nests in $1.0 \mathrm{~cm}$ diameter cavities (KURCZEWSKI 1976), while L. argentatus preferred $0.9 \mathrm{~cm}$ (RAU \& RAU 1918) and $0.7 \mathrm{~cm}$ (O'Brien \& KurCZEWSKI 1982).

The choice of cavity diameter can also be related to the adult female's decision on the gender of the wasps that will hatch from the eggs (O'NeILL 2001), particularly in species with sexual dimorphism in body size (KrombeIN \& Gingras 1984). This diameter choice based on the gender of the juvenile may directly influence the sex ratio of the emerged adults. Thus, caution is needed when evaluating the proportion between males and females at trap-nests due to the limited choices of the wasps (O’NeILl 2001).
Due to the lack of males emerging from the trap-nests, we were not able to measure the sex ratio of Liris sp. Thus, questions about male allocation and male/female nest differences remain to be explored. According to the 'split sex ratio' model proposed by Grafen (1986), eggs from which males are born could be laid at smaller burrows than those available in the present study, since only females emerged from the $0.5 \mathrm{~cm}$ diameter nests. Generally, males are born from smaller brood cells and with less food resources than female wasps (Polidori et al. 2011). BuschinI (2007) found, for Trypoxylon lactitarse Saussurre, 1867 (Crabronidae), that the sex ratio is related to nest diameter. This author observed a female-biased sex ratio at trap-nests with 1.0 and $1.3 \mathrm{~cm}$ diameters; otherwise, for the $0.7 \mathrm{~cm}$ diameter nests, the number of males were much greater, with a proportion of 19 males for 1 female at one year of study.

The absence of natural enemies was also observed for other species of Liris, even for L. argentatus nests, which is a very abundant species in North America (Krombein \& Gingras 1984). Nests of Liris sp. lack the three defensive structures commonly described for wasp nests: tight mud closures, intercalary and vestibular cells (Krombein 1967, O’Neill 2001). According to KROMbein (1967), using materials such as small twigs, leaves, exoskeleton of insects and lichens at nest closure could be part of the wasp's defensive strategy against natural enemies, since this architecture could work as a camouflage for the nest. This would be an important strategy for protection, mainly before cocoon spinning. However, it was observed that other species with the same defensive strategy are attacked by parasites (BARTHELEMY 2010, BuschinI \& WoIsKi 2006), a situation that is different from what was observed in this study.

The mixture of sand and silk used by Liris sp. for making the cocoon has been described for other wasps, also with the function of increasing the hardiness of the cocoon, and protecting the larvae against parasitism (Evans 1966). In our study we also observed sawdust left by the adult female, which may be a product of carvings made by the wasp at the trap-nest 
walls, and which may further increase the cocoon's hardiness. We believe that Liris sp. relies on the hardiness of the cocoon as its main defensive strategy against parasitism. It is possible that the time spent by the adult wasp accumulating debris at the bottom of the brood cell, which will be used by the larvae for cocoon-spinning, is connected with the fact that hard mud plugs and closure are not necessary. FreEman (1981) observed that the parasitoid Melittobia Westwood, 1847 (Eulophidae) has some difficulty entering the mud-made cocoon of Trypoxylon albitarse Fabricius, 1804.

We conclude that Liris sp. is a solitary wasp that nests in preexisting cavities, showing ground-nesting habits. As the other ground-nesting wasps of this genus, Liris sp. uses ground debris (sand and plant material) for nest closure. Other striking features of Liris sp. are the absence of parasitism, lack of nest defensive structures made of mud, resin or any harder material and a very hard cocoon made of sawdust, sand and silk. The hardiness of the cocoon is probably the main defensive strategy to protect the offspring, although it is complemented by the nest camouflage provided by the nest closure, mainly prior to cocoon spinning. Future studies should further explore the idea of a hard cocoon as the defensive strategy of wasp offspring instead of the construction of different nest structures, and if this is a particular feature of Liris wasps.

Finally, we also suggest that a broader comparison of the nesting biology of Liris should be carried out, leading to an understanding of the evolution of nest characteristics in this genus. This would bring new insights into the origin of the mixed behavior of cavity-nesting and ground-nesting observed for Liris sp.

\section{ACKNOWLEDGEMENTS}

We thank the Graduate Program in Entomology of the Universidade Federal do Paraná and the Program in Evolutionary Biology of the Universidade Estadual do Centro-Oeste for support during development of the present work. Financial support has been received through scholarships from Conselho Nacional de Desenvolvimento Científico e Tecnológico (CNPq). We also thank Bolívar R. Garcete Barrett of the Facultad de Ciencias Exactas y Naturales, Universidad Nacional de Asunción for the identification of the wasps. We also thank Laércio P. Amaral-Neto for the suggestions to the manuscript.

\section{LITERATURE CITED}

Aguiar AJC, Martins CF (2002) Abelhas e vespas solitárias em ninhos-armadilha na Reserva Biológica Guaribas (Mamanguape, Paraíba, Brasil). Revista Brasileira de Zoologia 19: 101-116. doi: 10.1590/S0101-81752002000500005

Amarante STP (2002) A synonymyc catalogue for the species of Neotropical Crabronidae and Sphecidae (Hymenoptera, Apoidea). Arquivos de Zoologia 37: 1-139.
Barthelemy C (2010) Nesting biology of Isodontia diodon (Kohl, 1890) (Hymemoptera: Sphecidae), a predator of cockroaches, in Hong Kong. Journal of Hymenoptera Research 19: 201-216.

Batista-Matos MC, Sousa-Souto L, Almeida RS, Teodoro AV (2013) Contrasting patterns of species richness and composition of solitary wasps and bees (Insecta: Hymenoptera) according to land-use. Biotropica 45: 73-79. doi: 10.1111/j.17447429.2012.00886.x

Bohart RM, Menke AS (1976) Sphecid wasps of the world: a generic revision. Berkeley, University of California Press.

Bosch J, MaEtA Y, Rust R (2001) A phylogenetic analysis of nesting behavior in the genus Osmia (Hymenoptera: Megachilidae). Annals of the Entomological Society of America 94: 617-627.

Buschini MLT (2007) Life-history and sex allocation in Trypoxylon (syn. Trypargilum) lactitarse (Hymenoptera; Crabronidae). Journal Zoological Systematics and Evolutionary Research 45: 206-213. doi: 10.1111/j.1439-0469.2006.00405.x

Buschini MLT, Luz V, Basilio S (2007) Comparative aspects of the biology of five Auplopus species (Hymenoptera; Pompilidae; Pepsinae) from Brazil. Journal Zoological Systematics and Evolutionary Research 45: 329-335. doi: 10.1111/j.14390469.2007.00407.x

Buschini MLT, WoIski TD (2006) Biology of the solitary wasp Isodontia costipennis Spinola 1851 (Hymenoptera Sphecidae) in trap-nets in southern Brazil. Tropical Zoology 19: 175-184.

Buschini MLT, Woiski TD (2008) Alpha-beta diversity in trap-nesting wasps (Hymenoptera: Aculeata) in southern Brazil. Acta Zoologica 89: 351-358. doi: 10.1111/j.14636395.2008.00325.x

Buschini MLT, Buss CE (2010) Biologic aspects of different species of Pachodynerus (Hymenoptera; Vespidae; Eumeninae). Brazilian Journal of Biology 70: 623-629.

Buschini MLT, Buss CE (2014) Nesting Biology of Podium angustifrons Kohl (Hymenoptera, Sphecidae) in an Araucaria Forest Fragment. Brazilian Journal of Biology 74: 493-500. doi: 10.1590/1519-6984.19112

Camillo E, Garófalo CA, Assis JMF, Serrano JC (1996) Biologia de Podium denticulatum Smith em ninhos armadilhas (Hymenoptera: Sphecidae, Sphecinae). Anais da Sociedade Entomológica do Brasil 25: 439-450.

Coville RE (1982). Wasps of the genus Trypoxylon subgenus Trypargilum in North America. Berkeley, University of California Press.

Evans HE (1966) The comparative ethology and evolution of the sand wasps. Cambridge, Harvard University Press.

FGBPN (2011) Plano de Manejo da Reserva Natural Salto Morato - Guaraqueçaba, PR. Curitiba, Fundação Grupo o Boticário de Proteção à Natureza.

Freeman BE (1981) The dynamics in Trinidad of Trypoxylon palliditarse: a Thompsonian population? Journal of Animal Ecology 50: 563-572. 
Grafen A (1986) Split sex ratios and the evolutionary origins of eusociality. Journal of Theoretical Biology 122: 95-121.

Krombein KV (1967) Trap-nesting wasps and bees. Life-histories, nests and associates. Washington, DC, Smithsonian Press.

Krombein KV, Gingras SS (1984) Revision of North American Liris Fabricius (Hymenoptera: Sphecoidea: Larridae). Smithsonian Contributions to Zoology 404: 1-96.

Kurczewski FE (1976) Behavioral observations on some Tachytini and Larrini (Hymenoptera: Sphecidae). Journal Kansas Entomological Society 49: 327-332.

Loyola RD, Martins RP (2006) Trap-nest occupation by solitary wasps and bees (Hymenoptera: Aculeata) in a forest urban remanent. Neotropical Entomology 35: 41-48.

Marco-Jr P DE, Vianna DM (2005) Distribuição do esforço de coleta de Odonata no Brasil - subsídios para escolha de áreas prioritárias para levantamentos faunísticos. Lundiana 6: 13-26.

Menke AS, Fernández C (1996) Claves ilustradas para las subfamilias, tribus y generos de esfecidos neotropicales (Apoidea: Sphecidae). Revista de Biologia Tropical 44: 1-68.

Morato EF, Amarante ST, Silveira OT (2008) Avaliação ecológica rápida da fauna de vespas (Hymenoptera: Aculeata) do Parque Nacional da Serra do Divisor, Acre, Brasil. Acta Amazonica 38: 789-798.

MourÃo APM, PANIZZI AR (2000) Estágios ninfais fotossensíveis à indução da diapausa em Euschistus heros (Fabr.) (Hemiptera: Pentatomidae). Anais da Sociedade Entomológica do Brasil 29: 219-225. doi: 10.1590/S0301-80592000000200003

NAscimento ALO, Garófalo CA (2014) Trap-nesting solitary wasps (Hymenoptera: Aculeata) in an insular landscape: Mortality rates for immature wasps, parasitism, and sex ratios. Sociobiology 61: 207-217. doi: 10.13102/sociobiology.v61i2.207-217

O’Brien MF, Kurczewski F (1982) Nesting and overwintering behavior of Liris argentata (Hymenoptera: Larridae). Journal of the Georgia Entomological Society 17: 60-68.

O’NeILl K (2001) Solitary Wasps: Behavior and Natural History. Ithaca, Cornell University Press.

Polidori C, Boesi R, Borsato W (2011) Few, small, and male: multiple effects of reduced nest space on the offspring of the solitary wasp, Euodynerus (Pareuodynerus) posticus (Hymenop- tera: Vespidae). Comptes Rendus Biologies 334: 50-60. doi: 10.1016/j.crvi.2010.11.003

Pulawski WJ (2015) Catalog of Sphecidae sensu lato - Liris. Available online at: http://researcharchive.calacademy.org/ research/entomology/entomology_resources/hymenoptera/ sphecidae/genera/Liris.pdf [Accessed: 21/07/2015]

R Development Core Team (2014) R: A language and environment for statistical computing. Vienna, The R Foundation for Statistical Computing, available online at: https://www.r-project.org [Accessed: 29/03/2015]

Rasmussen C, Camargo JMF (2008) A molecular phylogeny and the evolution of nest architecture and behavior in Trigona s.s. (Hymenoptera: Apidae: Meliponini). Apidologie 39: 102-118. doi: 10.1051/apido:2007051

Rau P, Rau N (1918) Wasp Studies Afield. London, Oxford University Press.

Ribeiro F, Garófalo CA (2010) Nesting behavior of Podium denticulatum Smith (Hymenoptera: Sphecidae). Neotropical Entomology 39: 885-891.

Stangler ES, Hanson PE, Steffan-Dewenter I (2015) Interactive effects of habitat fragmentation and microclimate on trap-nesting Hymenoptera and their trophic interactions in small secondary rainforest remnants. Biodiversity and Conservation 24: 563-578. doi: 10.1007/s10531-014-0836-X STEINER AL (1968) Behavioral interactions between Liris nigra Van der Linden (Hymenoptera: Sphecidae) and Gryllulus domesticus L. (Orthoptera: Gryllidae). Psyche (Stuttg) 75: 256-273.

Submitted: 17 November 2015

Received in revised form: 15 February 2016

Accepted: 30 March 2016

Editorial responsibility: Gabriel L.F. Mejdalani

Author Contributions: CCFC and MLTB designed the study. CCFC participated in fieldwork and analyzed the data. CCFC and MLTB wrote the manuscript.

Competing Interests: The authors have declared that no competing interests exist. 